\author{
Anna GRZEŚ, Ph.D. \\ Faculty of Economics and Management, University of Bialystok \\ e-mail: agrzes@uwb.edu.pl
}

DOI: 10.15290/ose.2017.01.85.07

\title{
DOES THE OUTSOURCING AFFECT LABOUR COSTS OF ENTERPRISES IN POLAND?
}

\begin{abstract}
Summary
This paper examines the impact of outsourcing materials and services on labour costs in two groups: industrial and construction enterprises, and services enterprises in Poland in the period 2005-2013. The analysis of this dependency was conducted on the basic of aggregated data coming from Polish enterprises classified in these two groups according to the PKD 20071. The preliminary analysis showed that Polish industrial and construction, and service enterprises applied both types of outsourcing, but outsourcing services had more important effect on labour costs than outsourcing materials. Econometric analysis confirmed that only outsourcing services had a positive but differential impact on labour cost per 1 worker in two groups, while outsourcing materials was responsible for negative, however weak, impact on these costs.
\end{abstract}

Key words: labour cost; materials outsourcing, services outsourcing; industrial and construction and services enterprises.

JEL: J30, L24, L60, L80

\section{Introduction}

The last few decades were marked by the growing popularity of outsourcing understood as separation of specific processes or functions outside and transferring them to capital-dependent or capital-independent domestic and foreign suppliers. This solution resulted in the reorganization of enterprises and their resources. The area of human resources is one of the areas of direct impact of outsourcing which in the short term experienced job losses and relocating the workplaces to foreign or domestic location, layoffs, or possibly moving them to the supplier. Quantitative reduction and qualitative adaptation in the level of employment was followed by decline in the overall level of labour costs, i.e. reduction of the fixed costs and enhancement of variable costs depending on the production volume. However, in the long term effects of outsourcing on employment,

\footnotetext{
1 PKD 2007 is consistent with NACE Rev. 2.
} 
wages, and labour productivity were different in economy and company scales, i.e. positive [eg. Linden et al., 2011, pp. 223-240], scant or neutral for the economy, although positive for highly skilled workers [Crino, 2010, pp. 253-256] or negative for semi-skilled or less specialised work [Baumgarten et al., 2013, pp. 132-152; Egger et al., 2001, pp. 257-272]. These examples of publications are based on data from developed countries, such as the USA, the UK, Germany. In regard to the Polish economy, the impact of outsourcing on the area of labour resources, particularly labour costs, seems to be relatively poorly recognised. Most of researchers primarily analyse the impact of final goods on trade and on international outsourcing (measured as exports and imports of intermediate goods) on employment and wages [Egger, Egger, 2002, pp. 83-96; Egger, Streher 2003, pp. 61-72], on industrial specialisation among Central and Eastern European Countries and directly on wages [Esquito, 2006]. The authors focus on Poland, Slovakia, and Hungary, analysing the issue separately for each country due to the specific characteristics of each of them.

The above-mentioned studies are steered towards the international dimension of business activities expressed in the impact of international outsourcing and offshoring on selected characteristics of the labour market. Meanwhile, the outsourcing phenomenon has a much broader scope because in practice many Polish firms, especially small and medium-sized, opt for an outsourcing contract with suppliers in the domestic market. In such situation, measuring outsourcing with import and export of intermediate goods is not justified, since it does not reflect the scale of the whole phenomenon, especially domestic outsourcing. Thus, there is a need for a different way of measuring, such as the cost of intermediate consumption i.e. intermediate materials and services used in the process of estimating the level of outsourcing in the particular country.

The purpose of this paper is to review the impact of outsourcing on the formation of labour costs in Polish companies, as well as analysing the strength of the relationship between these variables. In the context of the paper, a hypothesis was formulated that an increase in material outsourcing has a weak negative impact on growth of labour cost, but service outsourcing influence positively on growth of labor cost per worker in enterprise sector in Poland.

\section{The essence of outsourcing and methodology of its measurement}

The literature lacks clarity in the approach to define and measure outsourcing. The term is either used interchangeably with offshoring or treated as a separate concept [compare: Amiti, Wei, 2005, pp. 307-347; Olsen, 2006; Zorska, 2007, p. 36]. Therefore, in this article it was assumed that outsourcing is a separating of specific parts or even all of the processes / functions from the structure of the organization and transferring them to be carried out by external and dependent or independent business entities. Such a broad definition makes outsourcing cover two areas. The first one is the purchase of intermediate goods and services from external domestic and foreign suppliers. The second area is the transfer of workplaces to proximal and distal foreign locations and to domestic suppliers who produce semi-finished goods or perform services, e.g. Information 
Technology, accounting, human resources, security services, logistics, sales force, customer service, and other services to the principal. Given the definition of outsourcing above terms used in literature, were applied as follows: domestic outsourcing, international outsourcing, offshore outsourcing, offshoring, nearshoring, onshoring, shares services centers/ $\mathrm{BPO}$ centers, which all are forms of outsourcing chosen by enterprises seeking ways to improve economic efficiency. Depending on the needs, enterprises embrace one or several forms of outsourcing and the results of their activities in the area treat as: materials outsourcing reflected in the cost of intermediate materials, and service outsourcing recorded by the accounting as the cost of outside services.

The precise measurement of this phenomenon and its selected forms is difficult due to the incompatibility of the financial reporting to its character. In national statistics there are available data concerning imports and exports of intermediate goods. This availability may justify the popularity of international outsourcing among most researchers. In Polish companies, however, the domestic outsourcing dominates, so analysing the international outsourcing only would be a major simplification. For this reason author uses own approach to define the measure of total outsourcing. The overview of mandatory financial statements submitted by the enterprises allowed to identify economic categories that describe both the total outsourcing phenomenon in Polish enterprises as well as its international aspect. It should be noted that the international aspect of outsourcing, measured by import of intermediate goods, is included in the category of costs of materials and outside services from the financial reporting point of view, which indicates the implementation of outsourcing.

It is also worth referring to the classic Cobb-Douglas production function and its modifications, which show that the production depends on the capital, labour, technical and organisational progress, and random factor inputs. Assuming that outsourcing is a management tool now widely used in enterprises, there was consider it one of the factors of organisational progress affecting production. Thus, companies can enhance the production by increased employment and investment in fixed capital (including technologies) in order to improve labour productivity and the reorganization of functions associated with the outsourcing of parts of them, or mixed forms, and therefore affect the internal labour market. Theoretically speaking, with growth in production in the long term the company may increase outsourcing simultaneously maintaining or slightly increasing the number of employees, who often have higher qualifications. Such solution may contribute to the growth of labour costs. If we divide outsourcing into the outsourcing of materials and services, they might have different impact on labour costs.

The analysis of this dependence requires a look into the category of labour costs, which is a component of operating costs of the company. Given the availability of empirical data and the definition of the cost of labor present in the public statistics of the Central Statistical Office of Poland and Eurostat labour costs include: employee compensation, with wages and salaries in cash and in kind, employers' social security contributions is and employment taxes regarded as labour costs minus any subsidies received, and vocational training costs [Kos₹ty..., 2012, pp. 13-14].

The cost of labour is relatively heavily determined by the size and type of employment, but other factors may also have the impact on its level. They are: the increase in 
demand for more or less skilled workers, the supply of specific resources on the market, the presence of employer or employee market, the current level of labour costs in a particular region or type of business, the level of charges resulting from the employment of the employee. The aspects of the labour costs is complex and requires specific data to conduct studies. This paper takes into account general labour cost without separating them from one another.

\section{Review of the literature}

The current literature describing theoretical considerations and empirical research results focuses mostly on the aspect of the impact of offshoring or international outsourcing on employment, labour productivity or wages in one particular economy or selected few. It should be noted that the level of labour costs affects business efficiency, and is one of the key factors for offshoring, nearshoring, or onshoring.

When outsourcing includes both purchase of intermediate goods and services from external suppliers and the transfer of workplaces, moving to a foreign location is economically justified in case of lower total costs of implementation (i.e. labour costs, transportation costs, costs of providing the next batch of goods, complaints and repairs, etc.) of outsourced processes. As for national supplier locations, the lower cost of the service or the higher quality of the services provided at a given price by an outside company matter. For example, Egger and Stehrer [2003, pp. 61-72], Egger and Kreickemeier [2008, pp. 116-132]) outlined that international outsourcing causes inequalities in the area of employment and / or wages. Application of outsourcing gave birth to social fears of losing jobs and worsening the situation of workers in the labour market as a result of transferring the production processes, and later services, from highly developed countries to developing countries. Despite the decrease in the relative wages in developed countries, relative wages increased in service firms from developing countries [cf. Arndt 1997, pp.71-79; Kohler, 2001, pp. 31-53].

Hence, looking through the prism of enterprises, outsourcing in the short term is equated with a reduction in the level of employment and a reduction in payroll costs in enterprises. However, the long-term impact of outsourcing on wages, as the main component of labour costs, can be varied. Feenstra and Hanson conducted several studies on this issue. Their research showed that in 1972-1979 outsourcing was weakly negatively correlated with changes in relative, average, and annual wages of non-production workers, while in 1979-1990 it was positively correlated with changes in the relative employment of non-production workers [Feenstra, Hanson, 1996, pp. 240-247].

One of the main issues being discussed by researchers in another study was the impact of outsourcing on wages of skilled and unskilled workers. While examining the impact of import of intermediate materials (i.e. international outsourcing) on the wages of workers in the United States in the years from 1979 to 1990, Feenstra and Hanson [1996, pp. 240-247] recognised that this solution positively affected the wages of skilled American workers. When analysing the impact of US outsourcing (driven by Foreign Direct Investment) to Mexico, they found that wages of high-skilled workers increased 
is relation to low-skilled workers both in the USA and Mexico [Feenstra, Hanson, 1997, pp. 371-393].

In subsequent studies, these authors indicated that outsourcing and expenditures on new technologies such as investments in computers have an impact on wages. Their calculations showed that outsourcing is responsible in $15 \%$, and modern technologies in approx. 35\% for an increase in the relative wages of non-productive workers [Feenstra, Hanson, 1999, pp. 907-940]. Hijzen also came to similar conclusions [2007, pp. 188-205]. He noticed a significant impact of international outsourcing on wage inequalities, but also stresses that technological change is the main factor that affects these inequalities.

Amiti and Wei [2005, pp. 308-347; 2009, pp. 203-220] also did not find evidence that service outsourcing from the US and UK dramatically reduced job growth. Neverthless, based on the British Household Panel Survey, Geishecker and Görg [2008] showed widening of the wage gap between skilled and unskilled workers in the UK that outsourcing was responsible for. The most highly skilled workers received higher wages with outsourcing growth.

The above examples are related to developed economies which made decisions about international outsourcing or offshoring workplaces to developing countries and countries in Central and Eastern Europe. Egger and Egger were also interested in the impact of international outsourcing on wages in Eastern European countries [2002, pp. 83-89]. They investigated how international outsourcing (measured as intermediate trade) affected real wages in fourteen NACE two-digit industries of seven Central and Eastern European Countries (CEEC) such as Bulgaria, Czech Republic, Hungary, Poland, Romania, Slovenia, and Slovakia over the period 1993-1998. Using wage regressions they showed that intermediate goods export negatively affected wages in CEEC manufacturing, while the intermediate goods import had significantly positive impact. The authors explained that the difference in wage was caused by two opposite reasons. On the one hand, outsourcing to developing countries of CEE potentially raises the demand and consequently the growth of wages. On the other hand, the proportions of the labour force may change because of the changes in labour demand. Highly skilled workers may be offered jobs that are inadequate to their qualifications and therefore receive lower wages. Furthermore, EU-CEEC trade in final goods did not contribute to significant wage growth in real terms in 1996 in all countries, and in particular on Slovak and Polish wages.

Another study of Egger and Streher [2003] investigated the wages effect of outsourcing (measured as import and export of intermediate goods) in Poland, Czech Republic, and Hungary. The result of their research was that outsourcing caused a growth in the ratio of the wage bill of the manual and non-manual workers with more benefits for the second group. In addition, the second group of workers was more engaged in exports of intermediate goods than imports. Considerations proposed by Egger and Streher were developed by Esposito [2006]. He analysed the impact of final goods trade and outsourcing on the patterns of specialisation in manufacturing separately in Poland, Czech Republic, and Hungary in the period 1996-2004. Despite of production value, export and import of final and intermediate goods, he also took into account the annual average growth of the relative wage bill and its components: the relative employment and 
the relative wage. Econometric analysis of the impact of trade and outsourcing on relative wage bill of non-manual and manual workers in Poland partially confirmed that outsourcing measured as intermediate goods trade brought benefits for manual workers specialised in the production of labour intensive intermediate goods. In Czech Republic the shift of specialisation was similar, but productivity of manual labour was higher than in Poland. In contrast to Poland and Czech Republic, Hungary focused on the completion of imported intermediate goods using nonproduction workers more intensively. And that meant more benefits to this particular group of workers.

The above-mentioned studies show that the aspect of the impact of outsourcing on labour costs in highly developed countries is not a new phenomenon in the English literature. However, in regard to the entities operating in Polish economy it is a very poorly explored phenomenon. It should be noted, however, that one of the first studies of 250 large companies operating in the Polish economy conducted in 2005 by the Conference Board has shown that they are relatively willing to implement outsourcing of functions related to e.g. Information Technology, supply chain, and personnel management [Grześ, 2007, pp. 99-100]. Outsourcing in Polish industrial and construction industries and service entities intensified lately. These changes were also followed by changes in the internal labor markets, as shown in Figures 1 and 2.

FIGURE 1.

Growth rate of outsourcing and compensations in Polish industry and construction firms in the period 2005-2013 (constant prices, $2005=100$ )

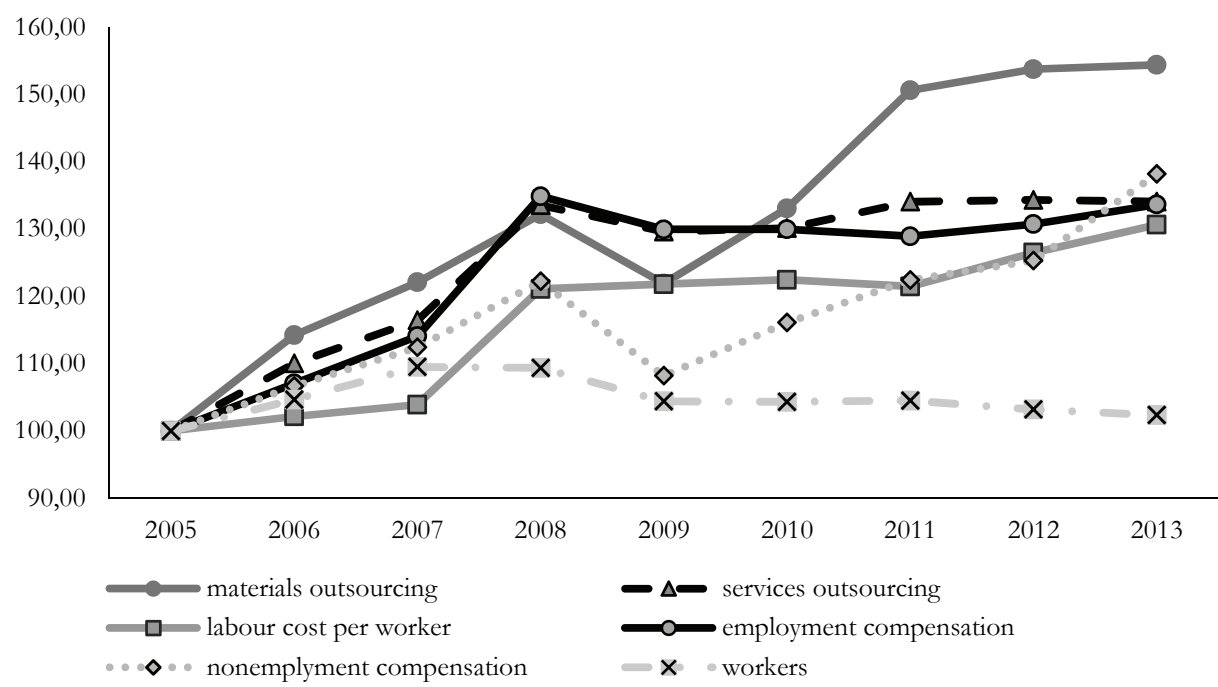

Source: Own accounts based on unpublished data of Central Statistical Office. 
FIGURE 2.

\section{Growth rate of outsourcing and compensations in Polish service firms in the period 2005-2013 (constant prices, $2005=100$ )}

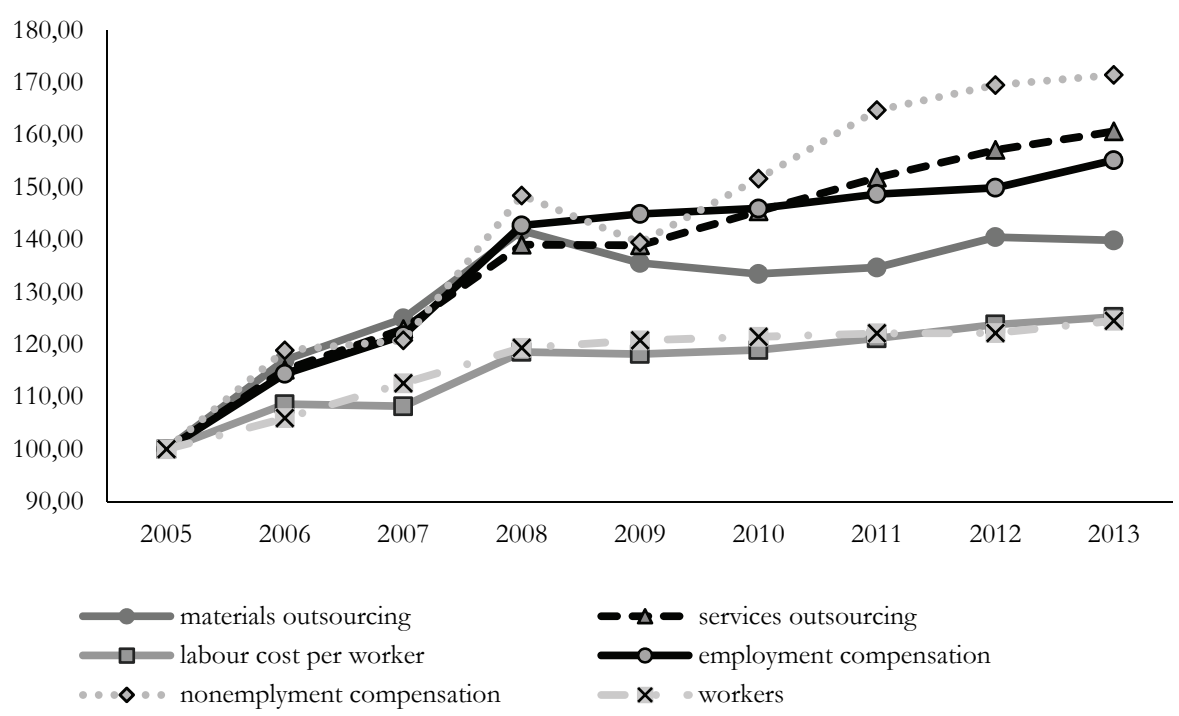

Source: Own accounts based on unpublished data of Central Statistical Office.

Shown in Figs. 1 and 2 data demonstrates that the analysed period can be divided into two sub-periods: the first period being 2005-2008 and the second 2009-2013. Basically, the first period is characterised by an increase in all the categories included in the analysis. It was only the second period that significantly differentiated the surveyed entities. Analysis of the curves of two basic forms of outsourcing, i.e. materials outsourcing and services outsourcing depends on the specific business entities' activities. In the analysed period, outsourcing in industrial and construction enterprises increased to $55 \%$, while service outsourcing increased to $35 \%$.

What is more, the real growth of outsourcing services has sustained at similar level from 2008, while an observation of business practice indicates that entities are interested in this type of outsourcing. This means that market competition on the market of outsourced services has led to lower their prices. Regardless of the recent financial crisis, they were less affected comparing to materials outsourcing, but after 2009 industrial and construction enterprises have again focused on outsourcing materials, slightly reducing employment, and varying forms of employment and labour costs. From 2009 nonemployment compensation has grown from 108\% to 138.2\%, while employment compensation has remained at the level of $130-133.6 \%$. It confirms that entities have used nonempoyment contracts (written order, contract work) more often or have hired employees through temporary work agency.

The curves in Fig. 2 show that service entities have also used outsourcing to improve sales. They were relatively more often used in service outsourcing than in materials 
outsourcing. It means that they signed contracts with subcontractors to carry out services for their principal whereas it can be noticed that this group of entities was less sensitive to the effects of financial crisis than the first described group. Outsourcing of services and materials has grown progressively during this period (i.e. at the level of $0.5-4.0 \%$ per year), much less affected by crisis.

Service entities noticed relatively large increase in the number of employees and nonemployment compensation. Number of employees in these enterprises increased in the studied period by $24.5 \%$. Meanwhile the number of workers in the first group increased to $109.38 \%$ in 2008 and then dropped to $102.37 \%$. Noneployment labour experienced the highest growth to $171.5 \%$ from $138.19 \%$ in industrial and construction entities. It confirms that service entities willingly benefited from nonemployment forms of workers' hiring.

\section{Methodology of the research}

To verify this type of economic phenomena, including outsourcing, three types of approaches are applied: the static approach based on resources (employment, the asset value), the dynamic (cumulative) approach based on cost or business flows, and the mixed approach. The physical effect of the use of outsourcing by the company is the purchase of intermediate goods in order to carry out the manufacturing processes. In order to define variables in the econometric model there was assumed an approach suggested by Kalinowski [2002, pp. 167-185] who studies the production functions based on the categories having the nature of streams. This approach allows to keep proportionality while comparing data. According to it, three basic factors can be identified: labour (L), capital (K), outsourcing (OUT). Costs of labour were used to measure the amount of labour $(\mathrm{L})$, and depreciation costs from tangible and intangible fixed assets were used to measure capital (K). Costs of materials and raw materials (excluding energy costs) and cost of outside services decide about the value of outsourcing (OUT). These categories of costs in terms of half-year and annual data in current prices are available in the financial statements F-01 / I-01 which are reported twice a year by all enterprises employing 10 and more workers. In order to make a comparison of the course of variables over time, current prices data have been submitted to the estimation of deflators: price index of sold production in the group of industrial and construction enterprises, and costumer price index (CPI) in the group of service companies given by the Central Statistical Office [2014].

In accordance with the applicable rules of reporting it was assumed that the international aspect of outsourcing measured mostly by the import of intermediate goods and services is included in the total value of outsourcing measured by categories of intermediate consumption. The value of sold goods and materials at purchase price and energy costs are not included in costs of consumption of intermediate production. The first category is connected with the main profile of the trading companies and is related to purchase goods for resale, while the second category, the energy, is ordered from external suppliers from the beginning. The author is aware that some of the costs 
of materials and raw materials, and ordered services are not associated with outsourcing. Nevertheless, due to the incompatibility of reporting to measure this particular phenomenon, these cost categories as derivatives of outsourcing were accepted in the form of business operations streams associated with it. This approach to measuring outsourcing is similar to one used by Girma, Görg [2004, pp. 817-832].

For the analysis of this issue the following aggregated data will be used: industrial and construction entities (PKD 2007 - Sections B, C, D, E, F that obtain), and services (section G, H, I, J, K, L, G, H, I, J, K, L, M, N, S). These data come from the enterprises with 10 and more persons employed, which keep books of accounts and conduct activity classified according to the PKD 2007. The research covers the years 2005-2013 and concerns the categories mentioned above at current prices, or the number of employees working in semiannual section, unpublished provided by the Central Statistical Office (GUS). Due to the nature of the activity the following service sections were left out: the field of education (Section P), health care and social assistance (Section Q), and culture, entertainment and recreation (section R). The labour (L) was expressed by labour cost category, which includes both wages resulting from the employment relationship as well as nonempoyment contracts. The author is aware that this period is relatively short, especially for an econometric model. However, extending this period was not possible due to significant changes in the Polish Classification of Activities (PKD 2004 change to the PKD 2007). Data coming from previous years, for example data from the years 2000-2004, is not comparable with data from the years 2005-2013. It is also worth emphasizing that this data set is also the largest possible to compare. For example, in 2013 the group of industrial and construction firms consisted of 16952 subjects, and the group of services firms consisted of 26834 subjects.

Firstly, the autor conducted the preliminary analysis of the dynamics of the basic variables in the annual intersection connected with the outsourcing of materials and services, labour costs, the number of employees, and production. Then based on aggregated data covering time series $\mathrm{N}=18^{2}$ an empirical verification of econometric model was conducted. This model was an attempt to determine the strength of the impact of outsourcing on labour costs in groups of enterprises mentioned above. To estimate the significance of the function of model parameters the classical least squares method of linear regression was used. Because of small number of time series $(N=18)$ the author treated this verification as preliminary to further research.

\section{Empirical verification of influence of outsourcing on labour costs of Polish enterprises in the period 2005-2013}

Conclusions from the preliminary analysis of the theory and the relationship between the variables (in logs): production value (Q), labour costs per worker $(\mathrm{Lcw})$,

\footnotetext{
2 Taking into account the semiannual frequency of gathering aggregated data in the period 20052013, it was possible to increase the number of periods (N) from 9 to 18 .

3 As was said in the methodology of research, because of change of the activity's classification PKD 2004 on PKD 2007 (that response NACE REV.2), so there was the longest available time series)
} 
materials (OUTm) and services outsourcing (OUTs), depreciation (D) for two groups of Polish enterprises were a base to verify the impact of two kinds of outsourcing on labour cost per 1 worker. Based on the methodology of the research described above, it was assumed that preceding independent variables could affect labour cost of industrial and construction (I model), and services (II model) firms as follows:

$$
\mathrm{Lcw}=\mathrm{F}(\text { OUTm, OUTs, } \mathrm{Q}, \mathrm{D})
$$

Following the stages of building an econometric model based on time series [Gruszczyński et al., 2006, Kufel, 2011] and using software GRETL structural parameters of regression models of function (1) were estimated (model I - for industrial and construction firms and II - for services firms). The method of least squares (OLS) was used.

In these two models the analysis of the non-stationarity of a time series using ADF test was conducted at first. After that, the statistical verification of each of the econometric models was proceeded using tests that assessed the significance of structural parameters, the fitting of the models to empirical data, normality of the residuals, multicollinearity of the independent variables, heteroscedasticity and autocorrelation of the error term, and the linearity of the analytical form of the model.

In models I and II the results of ADF test showed that the nonstationary of time series occurred. Statistical analysis of regression function based on such time series leads to incorrect conclusions. Stationarity can be achieved by first difference, eventually second difference [see: Charemza, Deadman, 1997, pp. 109-112; Greene, 2000, p. 776]. This way the regression of two models was estimated for second differences which caused elimination of this problem. In model I empirical value ADF (Augmented Dickey-Fuller) test without intercept for process $d \_d \_L c w$ was equal to $-3.573, p$ value $=0.00035$; $\mathrm{ADF}_{\text {emp }}$ with intercept $=-3.41$, $\mathrm{p}$ value $=0,01$, so hypothesis of a unit roots was rejected. Therefore, there were estimated cointegration relationships using Engle - Granger tests to find a satisfactory structure of this model. Testing for cointegration confirmed the variables are cointegrated because estimated regression ADF statistic for $I(2)$ and $m=2$ is equal to $-5.83, p$ value $=0.000002$. (On the significance level $5 \% \mathrm{ADF}_{\text {emp }}<$ $\left.\mathrm{ADF}_{\text {crit }}=-3,27\right)$. This means that long- and short-term parameters can be estimated [Maddala, 2006, p. 309].

In model II results empirical value ADF (Augmented Dickey-Fuller) test without intercept for process $d \_d \_L c w$ was equal to -3.545 , $p$-value $=0.00039$; for value $\mathrm{ADF}_{\text {emp }}$ with intercept $=-3.39, p$-value $=0.01$, so the hypothesis of a unit roots was rejected. Testing for cointegration confirmed the variables were cointegrated because estimated regression $\mathrm{ADF}$ statistic for $I(2)$ and $m=3$ is equal to -3.953 , $p$-value $=0.027$. (On the significance level $\left.5 \% \mathrm{ADF}_{\mathrm{emp}}<\mathrm{ADF}_{\text {crit }}=-3,63\right)$. Then it was assessed the significance of influence of the independent variables (OUTm, OUTs, Q, D) on the dependent variable $L o w$ using the t-Student test and omitted variable test like the sequential elimination of irrelevant variables in GRETL. Hence, the econometric models ${ }^{4}$ of two groups of firms were presented in Table 1 and Table 2.

\footnotetext{
${ }^{4}$ The estimated models contain only these variables that are significance on level $\alpha<0,05$ and above.
} 
TABLE 1.

Estimation of regression model of function using OLS for equation (1) for industrial and construction firms in 2005-2013, N=16 half-year periods and $\alpha=0.05$; dependent variable $\left(d \_d \_L c w\right)=d \_d \_l a b o u r$ cost per 1 worker

\begin{tabular}{|l|r|r|r|r|}
\hline \multicolumn{1}{|c|}{ Item (in ln) } & Coefficients & Standard error & t-Student & \multicolumn{1}{c|}{ p-value } \\
\hline d_d_OUTs & 0.346 & 0.0818 & 4.237 & $0.00088^{* * *}$ \\
d_d_D & 0.288 & 0.132 & 2.192 & $0.0458^{* *}$ \\
\hline
\end{tabular}

\begin{tabular}{|l|r|r|r|}
\hline R-squared $\left(\mathrm{R}^{2}\right)$ & 0.655 & Adjusted $\mathrm{R}^{2}$ & 0.630 \\
The sum of squared & 0.014 & Standard error & 0.0318 \\
residuals & 13.302 & Value p for test F & 0.00058 \\
$\mathrm{~F}(2,14)$ & 2.747 & & 0.682 \\
Durbin-Watson Stat. & 0.765 & Value p for test LM t \\
LM-nonlinearity test \\
(squares) \\
$\begin{array}{l}\text { Normality of residuals } \\
\text { Chi-squared }\end{array}$ & 1.287 & Value p for normality of \\
$\begin{array}{l}\text { VIF 5 } \\
\text { Stat for test of } \\
\text { autocorrelation LM }\end{array}$ & 4.001 & 0.5253 \\
Heteroscedacity test of & 4.15 & Value p for LM & \\
Breusch-Pagan & 0.873 & Value p for test Breusch- & 0.0625 \\
Pagan & 0.646 \\
\hline
\end{tabular}

Notes: significance levels: ${ }^{*} \alpha<0,1,{ }^{* *} \alpha<0,05$ and ${ }^{* * *} \alpha<0,01$

Source: Own accounts based on unpublished data of Central Statistical Office

From the data in Table 1 and 2 it can be inferred that the adjustment of models to empirical data is different. The model of sector of services firms (II) is relatively better fitted to empirical data than the model of sector of industrial and construction firms. Also tests of significance of parameters (test t-Student, F) and other tests mentioned above verifying the quality of the estimated model have confirmed that these models can be used to evaluate obtained estimates.

${ }^{5}$ In the regression model there are two independent variables, so VIF is the same for them. Conducted multicollinearity of independent variable revealed that this problem does not exist because value of VIF (Variance Inflator Factor) is below 10. It means that correlation between independent variables does not interfere with the quality of the constructed econometric model. [Gruszczyński et al., 2009, p. 58; Kufel, 2011, p. 65]. 
TABLE 2.

Estimation of regression model of function for equation (1) for service firms in 2005-2013 using OLS, $N=16$ half-year periods and $\alpha=0,05$; dependent variable $(\mathrm{Lcw})=$ labour cost per 1 worker

\begin{tabular}{|l|r|r|r|r|}
\hline \multicolumn{1}{|c|}{ Item (in ln) } & Coefficients & Standard error & t-Student & \multicolumn{1}{c|}{ p-value } \\
\hline d_d_OUTs & 0.527 & 0.125 & 4.207 & $0.001^{* * *}$ \\
d_d_OUTm & -0.1955 & 0.053 & -3.685 & $0.0027^{* * *}$ \\
d_d_D & 0.184 & 0.0302 & 6.087 & $3.86 \mathrm{e}-05^{* * *}$ \\
\hline
\end{tabular}

\begin{tabular}{|l|r|l|r|}
\hline R-squared R & 0.937 & Adjusted R & 0.928 \\
The sum of squared & 0.0051 & Standard error & 0.0199 \\
residuals & 64.905 & Value p for test F & $<0.000001$ \\
$\mathrm{~F}(3,13)$ & 2.808 & & \\
Stat DW & 1.628 & Value p for test LM t & 0.652 \\
LM-nonlinearity test & 1.534 & Value p for normality of residuals & 0.464 \\
Normality of residuals & $1.55-2.99$ & & 0.065 \\
VIF & 3.542 & Value p for LM & \\
Stat for test of & 1.872 & Value p for test Breusch-Pagan & 0.599 \\
autocorrelation LM & & & \\
Heteroscedacity test of & & \\
Breusch-Pagan & & \\
\hline
\end{tabular}

Notes: significance levels: ${ }^{*} \alpha<0,1,{ }^{* *} \alpha<0,05$ and ${ }^{* * *} \alpha<0,01$

Source: Own accounts based on unpublished data of Central Statistical Office

There are some differences in the impact of the kind of outsourcing on the labour cost per 1 worker in the period 2005-2013. In estimated first (I) model this cost is affected by services outsourcing and technological progress (measured as cost of depreciation). The variable of materials outsourcing has been recognised as irrelevant despite its high rate of growth especially in this group of industrial and construction firms. This aspect requests further analysis of factors which influenced the value of this variable. Obtained results concerning industrial and construction firms suggest that we can conclude with the probability of $95 \%$ that increase in services outsourcing contributed to positive three times lesser increasing the labour cost per 1 worker, ceteris paribus. Second variabledepreciation cost that is derived from the investment in fixed capital also had a positive but slightly lesser (3.57-times lesser than services outsourcing) impact on labour cost per 1 worker.

Assessment of adjustment variable in second model has shown that labour cost per worker was influenced additionally by materials outsourcing. However, the nature

${ }^{6}$ VIF for independent variables is respectively: d_d_OUTs $=2.9$, d_d_OUTm $=1.55$, d_d_D $=2.66$. 
of this impact has proved to be negative because increased materials outsourcing indicated relatively weak drop in labour cost per worker. Other factors, such as services outsourcing and depreciation, contributed to the growth of labour cost per worker. Their increase would be responsible for a positive, respectively: twice and three times lesser increase of the labour cost.

\section{Conclusion}

The theory and empirical research of outsourcing and labour costs presents different approaches to analysing this aspect. This dependence is discussed very often in the context of international outsourcing or offshoring jobs from developed to developing countries.

This paper looks at this relationship from a different perspective because it divides outsourcing into materials and services outsourcing. In order to measure these phenomena a cumulative approach was applied because it is based on adequate operating costs in half-year periods. This empirical study proved that both groups of Polish enterprises used outsourcing in their activity. Share of these types of outsourcing depends on specifics of the company. Preliminary analysis showed that industrial and construction firms used materials outsourcing more often but they still embraced services outsourcing. On the other hand, service firms increased services outsourcing. It was also noticed that labour costs grew in both groups of firms. The growth of these costs was caused by non-employment compensation in higher degree, especially in service firms.

Econometric analysis showed that labour costs per worker were affected positively by services outsourcing and depreciation cost. Their influence was different in these groups of influence of services outsourcing occurred in services firms than in industrial and construction ones, which can result from the character of their activity and regarding this tool as a way to increase the scale of activity. As was assumed in the hypothesis, the econometric analysis confirmed that service outsourcing had positive impact on labour cost per worker in two groups of enterprises, and that material outsourcing influenced negatively but only in service enterprises.

Similar results of two groups concerning depreciation suggest that investment in fixed capital brings relatively similar increase in labour cost per worker. This solution contributes to limitation of employment, but not necessarily to reduction of labour costs. However, due to the short time series, which is the result of the availability of comparable data, the author considers this analysis as a preliminary attempt to describe the phenomenon. This issue is complex and requires further research taking into account the specifics of labour costs.

\section{References}

Amiti M., Wei S. J., 2005, Fear of Service Outsourcing: Is it Justified?, "Economic Policy", Vol. 20(42), http://dx.doi.org/10.1111/j.1468-0327.2005.00140.x. 
Amiti M., Wei S. J., 2009, Service Offshoring, Productivity and Employment: Evidence from the US, “The World Economy", Vol. 32(2), http://dx.doi.org 10.1111/j.1467-9701. 2008.01149.x.

Arndt S. W., 1997, Globalization and Open Economy, "North American Journal of Economics \&Finance", 8(1). http://dx.doi.org/10.1016/S10629408(97)90020-6.

Baumgarten D., Geishecker I., Görg H., 2013, Offshoring, Tasks, and the Skill-Wage, "European Economic Review", Vol. 61(1), http://dx.doi.org/10.1016/j.euroecorev. 2013.03.007.

Charemza W. W., Deademan D. F., 1997, Nowa ekonometria, PWE, Warszawa.

Crino R., 2010, Employment Effects of Service Offshoring: Evidence from Matched Firms, "Economic Letters", Vol. 107(2).

Egger H., Egger P., 2002, How International Outsourcing Drives Up Eastern European Wages, "Weltwirtschaftliches Archiv", Vol. 138(1), http://dx.doi.org/10.1007/ BF02707324.

Egger H., Kreickemeier U., 2008, International Fragmentation: Boon or Bane for Domestic Employment?, "European Economic Review", Vol. 52(1), http://dx.doi.org/ 10.1016/j.euroecorev.2007.01.006.

Egger P., Pfaffermayr M., Wolfmayr-Schnitzer Y., 2001, The International Fragmentation of Austrian Manufacturing: The Effects of Outsourcing on Productivity and Wages, "The North American Journal of Economics and Finance", Vol. 12(3), http:/ /dx.doi.org/ 10.1016/S1062-9408(01)00051-1.

Ekonometria, 2006, (ed.) M. Gruszczyński, M. Podgórska, Szkoła Główna Handlowa, Warszawa.

Esposito P., 2006, The Effect of Trade and Outsourcing on the Industrial Specialisation in CEECs, http://www.aiel.it/Old/bacheca/UDINE/session_A/esposito.pdf (date of access: 24.02.2016).

Feenstra R. C., Hanson G. H., 1999, The Impact of Outsourcing and High-Technology Capital on Wages: Estimates for the U.S., 1979-1990, "Quarterly Journal of Economics", Vol. 114(3), http://dx.doi.org/10.1162/003355399556179.

Feenstra R. C., Hanson G., 1997, Foreign Direct Investment and Relative Wage: Evidence from Mexico's Maquiladoras, "Journal of International Economics", Vol. 42 (3/4). http://dx.doi.org/10.1016/S0022-1996(96)01475-4.

Feenstra R. C., Hanson G.H. 1996 Globalization, Outsourcing, and Wage Inequality, http://www.nber.org/papers/w5424.pdf (date of access: 01.03.2016), http://dx.doi.org/ $10.3386 / w 5424$.

Geishecker I., Görg H., 2008, Services Offshoring and Wages, "IZA Discussion Paper", No. 3593, Institute for the Study of Labour, Bonn.

Girma S., Görg H., 2004, Outsourcing, Foreign Ownership, and Productivity: Evidence from UK Establishment-Level Data, "Review of International Economics", Vol. 12(15).

Greene W. H., 2000, Econometric Analysis, Prentice Hall International, Inc.

Grześ A., 2007, Rola outsourcingu w zarzqdzaniu przedsiebiorstwem, [in:] Mechanizmy i obszary przeobrażeń w organizacjach, (ed.) A. Potocki, Difin, Warszawa.

Hijzen A., Swaim P., 2007, Does Outsourcing Reduce Industry Employment, "Nottingham Research Paper", Vol. 24. 
Kalinowski S., 2002, Zastosowanie funk.cji Cobba-Douglass do analizy procesów produk.cyjnych w przedsiebiorstwach przemystowych, "Ruch Prawniczy, Ekonomiczny i Socjologiczny", nr 1.

Kohler W. K., 2001, A Specific-Factors View on Outsourcing, "North American Journal of Economics and Finance", Vol. 12(1), http://dx.doi:10.1016/S1062-9408(00)000 43-7.

Koszty pracy w gospodarce narodowej w 2012 r., 2013, GUS, Warszawa.

Kufel T., 2011, Ekonometria. Rozwiazywanie problemów z.wykorzystaniem programu GRETL, PWN, Warszawa.

Linden G., Dedrick J., Kraemer K. L., 2011, Innovation and Job Creation in a Global Economy: The Case of Apple's iPod, "Journal of International Commerce and Economics", Vol. 3(1).

Maddala G. S., 2006, Ekonometria, PWN, Warszawa.

Olsen K. B., 2006, Productivity Impacts of Offshoring and Outsourcing: A Review. Statistical Analysis of Science, Technology and Industry, "STI Working Paper", 1, http://www.oecd.org/ officialdocuments/publicdisplaydocumentpdf/?cote=DSTI/DOC $\% 282006 \% 29$ $1 \&$ docLanguage $=$ En (date of access: 25.02.2016).

Zorska A., 2007, Outsourcing i przenoszenie ustug na świecie. Wnioski dla Polski, „Gospodarka Narodowa", No. 12. 